\title{
胸郭出口症候群牽引型と頝椎側面レ線との関連について
}

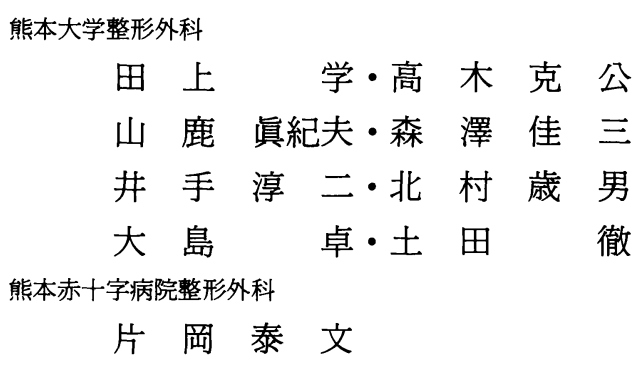

\section{Relation between Brachial Plexus Stretching Type of Thoracic Outlet Syndrome and Lateral View of Cervical Spine X-rays}

by

\author{
Manabu Tanoue, Katsumasa Takagi, Makio Yamaga, \\ Keizo Morisawa, Junji Ide, Toshio Kitamura, \\ Suguru Ohshima and Tohru Tsuchida \\ Department of Orthopaedic Surgery, \\ Kumamoto University School of Medicine, Kumamoto, Japan
}

Yasufumi Kataoka

Department of Orthopaedic Surgery, Kumamoto Red Cross Hospital, Kumamoto, Japan

We have reported that thoracis outlet syndrome (TOS) results not only from neurovascular compression but also from stretching and defined any such patients as brachial plexus stretching type of TOS. In 1984, T. R. Swift described that droopy shoulder syndrome (DSS) also results from brachial plexus stretching, and that in all patients with DSS, because of their characteristic features, the second thoracic or lower vertebrae visible above their shoulders on lateral view of cervical spine $\mathrm{X}$-rays are one of the diagnostic criteria for DSS. Therefore, we studied the relationship between brachial plexus stretching and the lateral view of cervical spine X-rays.

We examined 40 cases with brachial plexus stretching type of TOS from 1990 to 1993, in whom a neurography of the brachial plexus had been carried out. In 18 cases, $45 \%$ of them, lateral view of cervical spine X-rays demonstrated that the secone thoracic or lower vertebrae was above the level of the shoulders. Patients with brachial plexus stretching type of TOS had a "long neck". In 1990 Y. Kataoka reported that all patients whose second thoracic or lower vertebrae were visible above their shoulders on lateral view of cervical spine $\mathrm{X}$-rays had no symptoms induced by brachial plexus stretch. We found that this finding on X-rays did not always represent brachial plexus stretching and its symptoms.

Key words : Thoracic outlet syndrome (胸郭出口症候群), Brachial plexus stretching (腕神経丵牽引), Droopy shoulder syndrome (下垂肩症候群), Lateral view of cervical spine X-rays（頝 椎側面レ線像) 


\section{はじめに}

我々は胸郭出口症候群（以下 TOS と略す）の病態 に従来からの神経血管束の圧迫のみならず率引が関与 していることを見出し3), 腕神経叢の牽引が関与して いると考えられる TOSをTOS 牽引型として報告し てきた。一方, 1984 年 T. R. Swift は Droopy Shoulder Syndrome (以下 DSS と略す) の病態に腕 神経叢への毫引が関与していると推測し2)4), その特 徵的な体型から䅡椎側面レ線上第二胸椎椎体（以下 Th 2 椎体と略す) やそれより下位の椎体が観察され る所見を診断基準の一つとした ${ }^{4)}$.しかし診断基準は 全体として曖昧な点が多いことに加え, このレ線所見 が唯一客観的所見かのような印象を受ける。そこで DSS と同様に腕神経叢の牽引が関与していると考え られる TOS 牽引型の症例に対して䅡椎側面レ線を施 行し, 可視椎体レベルと腕神経鋠の率引との関連性, 即ち Th 2 椎体の観察される所見が腕神経叢の牽引を 示す必須条件と成り得るか否かを検討した.

\section{症例および方法}

1990 年〜1993 年に当科にて TOS と診断した症例 のうち, 腕神経叢造影検査を用い, TOS 牽引型と診 断した 40 症例 (男性 3 症例, 女性 37 症例), 年齢 13〜44 才（平均 25.8 才）を対象とした。なお臨床症 状および腕神経叢造影検査所見は片岡らの基準に従っ て評価した ${ }^{3)}$. その結果, 40 症例中, 臨床上圧迫症状 より牽引症状を強く認め, かつ腕神経叢造影検査にて 圧迫所見より毫引所見を強く認める Type IIIが 30 症 例と牽引症状・率引所見のみを認める Type IVが 10 症例であった。

全症例に頝椎側面レ線を中間位にて撮影し，鎖骨上 で観察される最下位の椎体を可視椎体とした．また， 可視椎体の判定も片岡らの方法に従い 3 段階に分けて 評価した ${ }^{1)}$.

$$
\text { 結果 }
$$

可視椎体は Th 1 椎体上位 $1 / 3$ 椎体幅 から Th 3 椎 体下位 $3 / 3$ 椎体幅 までの範囲で観察され, 平均は Th 2 椎体上位 $1 / 3 \pm 2 / 3$ 椎体幅であった（図 1 ). Th 2 椎体の観察できた症例は Type IIIの中に 13 症例 $(43$ \%), Type IVの中に 5 症例 $(50 \%)$, 合計 40 例中 18 例（45\%）に見られた（図 2).

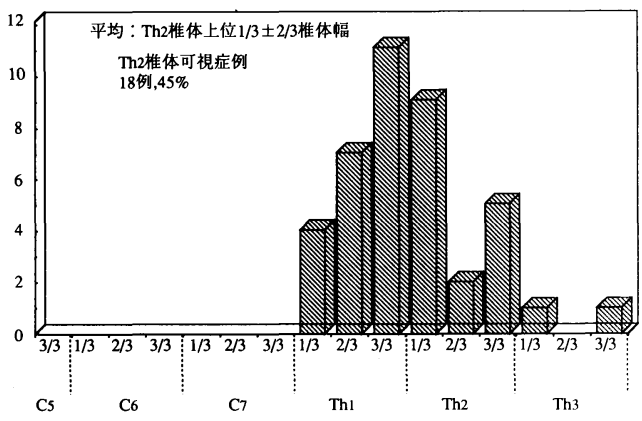

図 1 TOS 牽引型の可視椎体分布（1） 可視椎体は Th 1 椎体上位 $1 / 3$ 椎体幅 から Th 3 椎体 下位 $3 / 3$ 椎体幅の範囲で観察された。

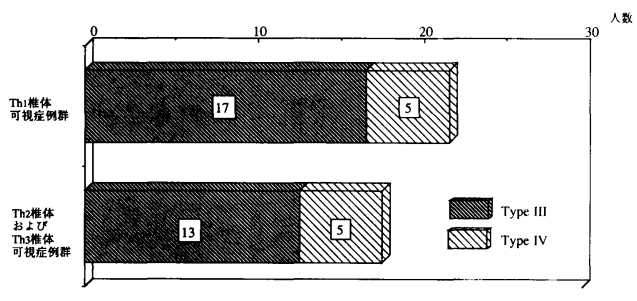

図2 TOS 型の可視椎体分布 (2) Th 2 椎体可視症例は 18 症例（45\%）に認められた。

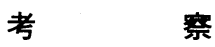

片岡の報告によれば, 無作為抽出の 500 例の頝椎側 面レ線可視椎体分布は, C 5 椎体下位 $1 / 3$ 椎体幅 か ら $\mathrm{Th} 3$ 椎体下位 $3 / 3$ 椎体幅 の範囲で観察され, 平均 $\mathrm{Th} 1$ 椎体中央 \pm 1 椎体幅であり, その内 $\mathrm{Th} 2$ 椎体よ り下位椎体の観察された症例は 52 例 $(10.4 \%)$ に認 められた (図 3$)^{1)}$. 一方今回調査した TOS 型の 可視椎体分布をこれと比較すると, TOS 毫引型症例 の可視椎体はより下位まで観察され，“首の長い”の 傾向にあった。

対象とした 40 症例のうち, DSS の基準である $\mathrm{Th}$ 2 椎体より下位椎体が観察される所見は 18 例 (45\%) に認められたが，22 例（55\%）には認められなかっ た. 即ち, 腕神経叢が牽引されていても Th 2 椎体が 観察されない症例が存在した。

また, 片岡は前述の 500 例の中の Th 2 椎体可視症 例 52 例（10.4\%）に対して, 頝部から上肢にかけて の疼痛・しびれ感, 上肢の下方ストレスによる症状の 増悪などに代表されるDSS 症状, 即ち, 腕神経叢の 牽引によって生じる症状を調查した結果, 調査し得た 


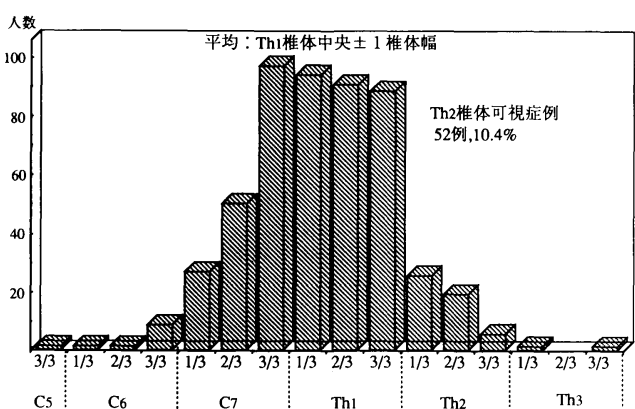

図 3500 症例における可視椎体分布（片岡の文献より 1)） 可視椎体はC 5 椎体下位 $3 / 3$ 椎体幅から Th 3 椎体下位 $3 / 3$ 椎体幅の範囲で観察された。

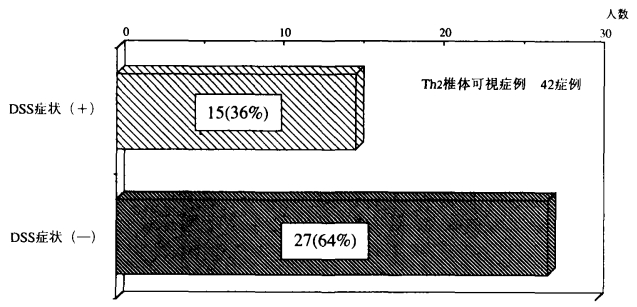

図 4 Th 2 椎体可視症例と DSS 症状（片岡の文献より 1)） Th 2 椎体可視症例の中に DSS 症状を認めない 27 症例 (64\%) が存在した。

42 例中 15 症例 (36\%) の DSS 症状を認める症例群 と 27 症例 $(64 \%)$ の DSS 症状を認めない症例群があっ たことを報告している（図 4 ）。そして，Th 2 椎体が 観察されても, 腕神経叢の症状を必ずしも呈する
とは限らないと考察している ${ }^{1)}$.

腕神経叢が毫引されていてもTh 2 椎体の観察され ない症例が $55 \%$ 存在すること，また，Th 2 椎体が観 察されても㐮引症状のない症例が $64 \%$ 存在すること から, Swift が基準としている可視椎体レベル, 即ち, 頝椎側面レ線上 Th 2 椎体およびそれより下位の椎体 が観察されるという DSS の基準は，腕神経叢の牽引 という病態とそれに起因する症状を示す必須条件では ないと考えられた。

結 語

1. TOS 型 40 例に頝椎側面レ線を施行し, 腕 神経叢の毫引との関連性を検討した。

2. TOS 毫引型患者は “首の長い”傾向にあった。

3.Th 2 椎体およびそれより下位の椎体が観察さ れるという所見は，腕神経叢の牽引とそれに起因する 症状を示す必須条件ではないと考えられた。

\section{参 考 文 献}

1) 片岡泰文ほか：Droopy shoulder syndrome と頝椎側 面の X-P の関連について. 整形外科と災害外科, 39 : $545-548,1990$.

2) 片岡泰文ほか: The Droopy Shoulder Syndrome の検 討. 肩関節, $14: 56-59,1990$.

3）片岡泰文ほか：腕神経叢造影による TOS のタイプ分 類と手術成績について。肩関節，15：262-267，1991.

4) Swift, T. R. and Nichols, F. T. : The droopy shoulder syndrome. Neurology, $34: 212-215,1984$. 